\title{
Correction to: Analytical Solutions for Tunnels of Elliptical Cross-Section in Rheological Rock Accounting for Sequential Excavation
}

\author{
H. N. Wang ${ }^{1,2} \cdot$ S. Utili ${ }^{3} \cdot$ M. J. Jiang ${ }^{1,4,5} \cdot$ P. $\mathrm{He}^{4}$
}

Published online: 18 February 2020

(c) The Author(s) 2020

\section{Correction to: Rock Mech Rock Eng (2015) 48:1997-2029 https://doi.org/10.1007/s00603-014-0685-7}

The article Analytical Solutions for Tunnels of Elliptical Cross-Section in Rheological Rock Accounting for Sequential Excavation, written by H. N. Wang, S. Utili, M. J. Jiang, P. He, was originally published Online First without Open Access. After publication in volume 48, issue 5, page 1997-2029, the author decided to opt for Open Choice and to make the article an Open Access publication. Therefore, the copyright of the article has been changed to (C) The Author(s) 2020 and the article is forthwith distributed under the terms of the Creative Commons Attribution 4.0 International License (http://creativecommons.org/licenses/ by/4.0/), which permits use, duplication, adaptation, distribution and reproduction in any medium or format, as long as you give appropriate credit to the original author(s) and the source, provide a link to the Creative Commons license, and indicate if changes were made.

The original article can be found online at https://doi.org/10.1007/ s00603-014-0685-7.

H. N. Wang

wanghn@tongji.edu.cn

1 State Key Laboratory of Disaster Reduction in Civil Engineering, Tongji University, Shanghai 200092, China

2 School of Aerospace Engineering and Applied Mechanics, Tongji University, Shanghai 200092, China

3 School of Engineering, University of Warwick, Coventry CV4 7AL, UK

4 Department of Geotechnical Engineering, College of Civil Engineering, Tongji University, Shanghai 200092, China

5 Key Laboratory of Geotechnical and Underground Engineering of Ministry of Education, Tongji University, Shanghai 200092, China
Open Access This article is licensed under a Creative Commons Attribution 4.0 International License, which permits use, sharing, adaptation, distribution and reproduction in any medium or format, as long as you give appropriate credit to the original author(s) and the source, provide a link to the Creative Commons licence, and indicate if changes were made. The images or other third party material in this article are included in the article's Creative Commons licence, unless indicated otherwise in a credit line to the material. If material is not included in the article's Creative Commons licence and your intended use is not permitted by statutory regulation or exceeds the permitted use, you will need to obtain permission directly from the copyright holder. To view a copy of this licence, visit http://creativecommons.org/licenses/by/4.0/.

Publisher's Note Springer Nature remains neutral with regard to jurisdictional claims in published maps and institutional affiliations. 